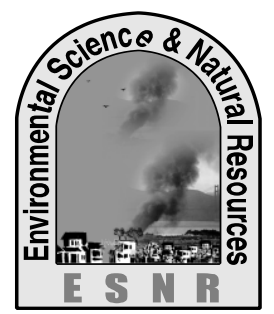

\title{
Effects of Industrial Wastewater on the Yield and Trace Element Contents of Red amaranth
}

\author{
N. Sultana ${ }^{1}$, N. Nawshin ${ }^{1}$, H. Muktadir ${ }^{1}$, M. A. H. Chowdhury ${ }^{2}$ and M. A. Baten ${ }^{1 *}$ \\ ${ }^{1}$ Dept. of Environmental Science, ${ }^{2}$ Dept. of Agricultural Chemistry, \\ Bangladesh Agricultural University, Mymensingh-2202 \\ *Corresponding author: baten_envsc@yahoo.com
}

\begin{abstract}
Assessment the effect of industrial wastewater on the yield and trace element contents of red amaranth was carried out by this study. Thirty wastewater samples were collected from five major environment-polluting industries namely pharmaceuticals, dyeing, leather, food, and plastic industries at three different locations. Atomic Absorption Spectrophotometer was used for analyzing the trace elements in the wastewater-irrigated samples of red amaranth. Higher mean concentrations of $\mathrm{Pb}, \mathrm{Cd}, \mathrm{Ni}, \mathrm{Cr}, \mathrm{As}, \mathrm{Zn}$, and $\mathrm{Cu}$ in red amaranth were $0.97,0.20,1.23,52.72,0.52,0.85$, and $2.62 \mu \mathrm{g} \mathrm{g}^{-1}$. The percentage of yield reduction in red amaranth were 11.06 , $12.73,14.07,3.46,7.82 \%$ for $T_{2}, T_{3}, T_{4}, T_{5}$ and $T_{6}$ respectively compared to distilled water control $\left(\mathrm{T}_{1}\right)$. The results concludes that the wastewater samples of pharmaceuticals, dyeing, leather and plastic industries were more polluted than the wastewater of food industries. Vegetables grown in industrial areas contain trace elements viz. $\mathrm{Cr}, \mathrm{Ni}$ and $\mathrm{Cu}$ which would be health hazardous for consumer.
\end{abstract}

Key words: Heavy metals, Red amaranth, Wastewater and Yield

\section{Introduction}

All over the world industrial pollution has been increasing day by day and effluents from those industries is one of the major sources of environmental pollution. Metals in vegetables coming from the irrigation of industrial effluents are detrimental to human health. Plants and vegetables take elements up by absorbing them from contaminated soils and wastewater used for irrigating them as well as from deposits on different parts of the plants (Funtua et al., 2008). Vegetables, especially those of leafy vegetables grown in trace elements contaminated wastewater and soils, accumulate higher amounts of metals (Muhammad et al., 2008). They accumulate trace elements in their edible and non-edible parts. Absorption capacity of trace elements depends upon the nature of vegetables and some of them have greater potential to accumulate higher concentrations of metals than others (Akan et al., 2009).

Discharged from pesticides, textiles, chemicals, fertilizers, pulp and paper, paints, pharmaceuticals, tannery industries contains trace elements like $\mathrm{Pb}, \mathrm{Cd}$, $\mathrm{Ni}, \mathrm{Cr}, \mathrm{As}, \mathrm{Zn}, \mathrm{Cu}, \mathrm{Hg}$ etc. Excess concentrations of these trace elements have the ability to inhibit plant growth and the development of aquatic life by bioaccumulation. Concerning issues is that the industrial discharge mixed with drainage system, canal, or river water system and the water is used without knowing the after effects to grow crops and vegetables in city area where supplies of good-quality water are limited. It has recently been estimated that about 20 million hectares of land are irrigated with treated, partially treated, diluted, and untreated wastewater in developing countries to grow vegetables or other crops (Scott et al., 2004; Keraita et al., 2008).

In Bangladesh, vegetables especially leafy vegetables grown with irrigating canal or river water polluted by industrial effluents is a routine practice because of the availability and free of cost. Transformation of toxic trace elements from soil or water to plant body may cause an enormous damage to productivity, growth, and product safety of vegetables. Exposure of vegetables to these toxic metals can also pose a variety of physiological and biochemical disorders in human body. Considering these facts in mind, the experiment was designed to study the effects of industrial wastewater on the yield and trace elements contents of red amaranth.

\section{Materials and Methods}

\section{Study area}

Three sampling sites were selected for wastewater sampling depending on the degree of industrialization process and wastewater characteristics. Gazipur district located in between $23^{\circ} 53^{\prime}$ and $24^{\circ} 21^{\prime}$ north latitudes and in between $90^{\circ} 09^{\prime}$ and $92^{\circ} 39^{\prime}$ east longitudes, Hazaribagh situated in $90^{\circ} 21^{\prime}$ east longitudes and $23^{\circ} 45^{\prime}$ north latitudes and location of Mymensingh district is in between the latitudes $24^{\circ} 15^{\prime}$ and $25^{\circ} 15^{\prime}$ North and $90^{\circ} 05^{\prime}$ and $90^{\circ} 50^{\prime}$ East longitudes (Fig. 1). Pot experiment was carried in the Bangladesh Institute of Nuclear Agriculture (BINA), Mymensingh.

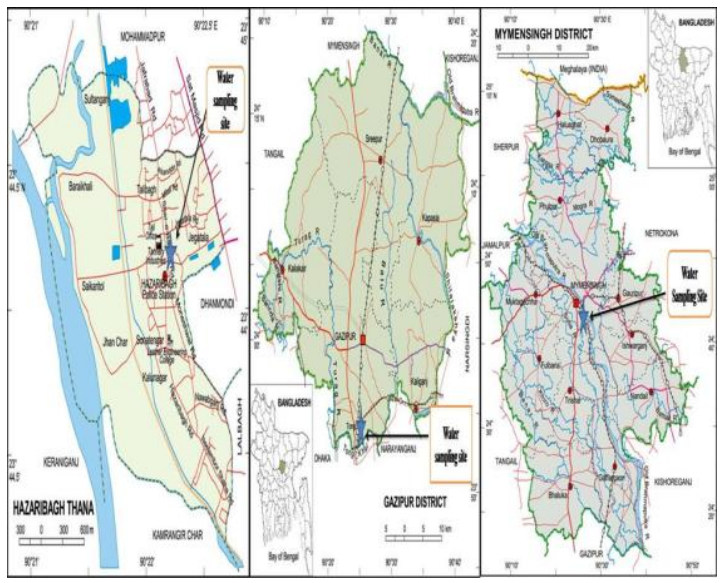

Fig. 1. Map of the study area 


\section{Collection and preparation of water samples}

Wastewater samples were collected from the drainage system of five types of industries where industrial effluents are discharged. After filtering the collected samples, five to six drops of liquid toluene were added to control microbial growth.

The concentrations of trace elements like $\mathrm{Cr}, \mathrm{Cu}, \mathrm{Zn}$, and $\mathrm{Pb}$ in samples were analysed by atomic absorption spectrophotometer (Spectr AA-55B) at the Soil Science Division, Bangladesh Agricultural Research Institute (BARI).

\section{Test crop and pot preparation}

BARI Lal shak-3 was used as test crop and seeds were collected from the institute (BARI). Soil samples were collected from the field laboratory of Bangladesh Institute of Nuclear Agriculture (BINA). The soils were sun dried for several days, sieved through 10-mesh sieve and mixed thorouhly. Significant amount of sieved soil was kept in a polythene bag for experiment. Thirty two (32) plastic pots were selected for the experiment. Individual pot size was $15 \mathrm{~cm}$ diameter at the top and $12 \mathrm{~cm}$ diameter at the bottom with $10 \mathrm{~cm}$ depth. Each labeled pot was filled with $1.5 \mathrm{~kg}$ finely sieved soil leaving $3 \mathrm{~cm}$ from the top.

\section{Seed germination and treatment}

The seeds were germinated uniformly after 6 to 8 days of sowing. The germination rate was approximately $98 \%$.

The experiment comprised of six treatments. The wastewaters of five industries were considered as treatments including a control. The treatments were as follows;

$\mathrm{T}_{1}=$ Control (Distilled water)

$\mathrm{T}_{2}=$ Pharmaceuticals

$\mathrm{T}_{3}=$ Dyeing

$\mathrm{T}_{4}=$ Leather

$\mathrm{T}_{5}=$ Food

$\mathrm{T}_{6}=$ Plastic

Water was applied twice a day after 20 days to 45 days of sowing.

\section{Data collection}

From each pot, 3 plant samples were harvested after 20 days of sowing and 45 days of sowing after wastewater treatment. Then the samples were tagged and the plant height, shoot and root weight, number of branch and leaf, total fresh and dry weight of red amaranth were recorded in the laboratory of Environmental science, BAU. Their mean values were calculated from the samples.

\section{Digestion of plant samples}

Dried samples were powdered using a pestle and mortar and sieved. All reagents were of analytical reagent grade $69-72 \% \mathrm{HNO}_{3}, 30 \% \mathrm{H}_{2} \mathrm{O}_{2}$, and $70 \% \mathrm{HCIO}_{4}$ were used for digestion of samples. Double deionised water was used for all dilutions. During the experiments, all glassware's and equipment were carefully cleaned. Samples were digested with $10 \mathrm{~mL}$ of $\mathrm{HNO}_{3}, 2 \mathrm{~mL}$ of $\mathrm{H}_{2} \mathrm{O}_{2}$, and $4 \mathrm{~mL}$ of $\mathrm{HCIO}_{4}$ in block digester system maintaining the temperature of 180-200

${ }^{\circ} \mathrm{C}$ until white fumes were evolved and finally diluted to $50 \mathrm{~mL}$ distilled water. All sample solution was clear.

Trace elements analyses in red amaranth

Trace elements $(\mathrm{Pb}, \mathrm{Cd}, \mathrm{Ni}, \mathrm{Cr}, \mathrm{As}, \mathrm{Zn}$ and $\mathrm{Cu})$ concentrations in the extract of processed samples were determined by atomic absorption spectrophotometer (Spectr AA-55B) at the Soil Science Division, Bangladesh Agricultural Research Institute (BARI) Gazipur.

\section{Results and Discussion}

\section{Plant height}

The plant height was recorded from all samples before and after wastewater treatment. Before wastewater treatment the measured plant height ranged from 27.5 to $29.0 \mathrm{~cm}$. After applying $\mathrm{T}_{2}, \mathrm{~T}_{3}$, and $\mathrm{T}_{4}$ the plant height were decreased from 28.9 to $26.5,27.6$ to 26.4 , and 28.9 to $27.0 \mathrm{~cm}$, respectively. On the other hand, plant height was increased from 28.8 to $29.7 \mathrm{~cm}, 28.4$ to 29.1 $\mathrm{cm}$, respectively after the application of $\mathrm{T}_{5}$ and $\mathrm{T}_{6}$ (Table 1). According to Islam et al. (2006) after 35 days of sowing of red amaranth, the plant height was recorded $27 \mathrm{~cm}$.

\section{Branch and leaf number}

Remarkable influence on branch and leaf number of red amaranth was observed due to different industrial wastewater treatment. Before treatment, the higher and lower branch numbers were 9.50 and 8.17 , respectively. After wastewater application, branch number was slightly decreased from 9.5 to $7.9,9.1$ to $7.7,8.5$ to 7.8 , 8.0 to 8.1 , respectively. The branch number was increased from 9.2 to 9.6 where $\mathrm{T}_{5}$ was applied. Leaf number also slightly decreased from 21.7 to $21.1,21.3$ to 20.5 , and 20.5 to 18.9 , respectively after the application of $\mathrm{T}_{2}, \mathrm{~T}_{3}$, and $\mathrm{T}_{4}$ compared to before treatment (Table 1 and Fig. 2). The leaf number of the plant treated by $\mathrm{T}_{5}$ increased from 22.8 to 23.3 .

\section{Fresh shoot and root weight}

Fresh shoot and root weight was considerably affected by the application of wastewater of different industries. After the application of $\mathrm{T}_{2}, \mathrm{~T}_{3}$, and $\mathrm{T}_{4}$ the fresh shoot weight of red amaranth was reduced from 7.6 to 7.3, 7.5 to 7.4 , and 7.3 to $7.2 \mathrm{~g}$, respectively. Both shoot and root weights were increased after the treatment of $\mathrm{T}_{5}$ and $\mathrm{T}_{6}$ (Table 1 and Fig. 2). Root weight of the plant treated with the wastewater of pharmaceuticals and dyeing industries decreased from 0.66 to 0.63 and 0.65 to $0.61 \mathrm{~g}$, respectively.

\section{Dry weight}

Dry weight of 3 plants per pot before and after wastewater treatment were observed among all treatments ranging from 3.3 to $3.8 \mathrm{~g}$ and 2.8 to $3.8 \mathrm{~g}$, respectively. After wastewater treatment, the higher dry weight was recorded in $T_{5}$ and lower dry weight was recorded in $\mathrm{T}_{2}$ and $\mathrm{T}_{4}$ (Table 1 and Fig. 2). 
Table 1. Effects of different industrial wastewater on the plant height, leaf and branch number, root and shoot weight of red amaranth

\begin{tabular}{|c|c|c|c|c|c|c|c|c|c|c|c|c|}
\hline \multirow[t]{2}{*}{ Treatments } & \multicolumn{2}{|c|}{$\begin{array}{c}\text { Plant Height } \\
(\mathrm{cm})\end{array}$} & \multicolumn{2}{|c|}{ Leaf no. } & \multicolumn{2}{|c|}{ Branch no. } & \multicolumn{2}{|c|}{$\begin{array}{c}\text { Fresh Shoot } \\
\text { weight (g) }\end{array}$} & \multicolumn{2}{|c|}{$\begin{array}{l}\text { Fresh Root } \\
\text { weight (g) }\end{array}$} & \multicolumn{2}{|c|}{$\begin{array}{c}\text { Dry weight } \\
\text { (g) }\end{array}$} \\
\hline & B.T & A.T & B.T & A.T & B.T & A.T & B.T & A.T & B.T & A.T & B.T & A.T \\
\hline $\mathrm{T}_{1}$ & & 31 & & 23.6 & & 9.7 & & 8.2 & & 0.75 & & 3.9 \\
\hline $\mathrm{T}_{2}$ & 28.9 & 26.5 & 21.7 & 21.1 & 9.5 & 7.9 & 7.6 & 7.3 & 0.66 & 0.63 & 3.6 & 2.8 \\
\hline $\mathrm{T}_{3}$ & 27.6 & 26.4 & 21.3 & 20.5 & 9.1 & 7.7 & 7.5 & 7.1 & 0.65 & 0.61 & 3.6 & 2.9 \\
\hline $\mathrm{T}_{4}$ & 28.9 & 27 & 20.5 & 18.9 & 8.5 & 7.8 & 7.3 & 7 & 0.65 & 0.66 & 3.5 & 2.8 \\
\hline $\mathrm{T}_{5}$ & 28.8 & 29.7 & 22.8 & 23.3 & 9.2 & 9.6 & 7.7 & 7.8 & 0.69 & 0.75 & 3.8 & 3.8 \\
\hline $\mathrm{T}_{6}$ & 28.4 & 29.1 & 21.4 & 20 & 8.1 & 8.1 & 7.3 & 7.5 & 0.61 & 0.67 & 3.3 & 3.5 \\
\hline
\end{tabular}

Note: After treatment (A.T), Before treatment (B.T).

\section{Yield of red amaranth}

Average yield of red amaranth treated with distilled water was $8.95 \mathrm{~g}$. The yield reduction compared to distilled water application was 11.0, 12.7, 14.0, 3.3, and $7.4 \%$ for $\mathrm{T}_{2}, \mathrm{~T}_{3}, \mathrm{~T}_{4}, \mathrm{~T}_{5}$, and $\mathrm{T}_{6}$ respectively (Table 2 ). The following table also shows that higher yield reduction (14.0 and $12.7 \%$ ) was occurred in $\mathrm{T}_{3}$ and $\mathrm{T}_{4}$ treated plant. The effluents used as $\mathrm{T}_{3}$ and $\mathrm{T}_{4}$ contain high concentration of EC and other trace elements $(\mathrm{Cr}$, $\mathrm{Cd}$ etc) compared to other treatment. In this study this high concentration of EC and presence of other trace elements may be caused the higher yield reduction in treatment $\left(\mathrm{T}_{3}\right.$ and $\left.\mathrm{T}_{4}\right)$. High EC indicates the presence of excess salinity that restricts the availability of water to plants by lowering the total water potential in the soil, impact on crop physiology and yield (Goel, 2006). On the other hand, a study reported that the high concentration of $\mathrm{Cr}$ seriously reduced leaf chlorophyll, root, and shoot length (Jushi et al., 1999). High level of $\mathrm{Cd}$ show visible symptoms of injury reflected in terms of chlorosis, growth inhibition, browning of root tips and finally death (Guo et al., 2008). Effluents of food industries contain lower concentration of EC and other trace elements because of the presence of microbial activity. In this study, lower yield reduction 3.3 and $7.8 \%$ was occurred in $\mathrm{T}_{5}$ and $\mathrm{T}_{6}$

A

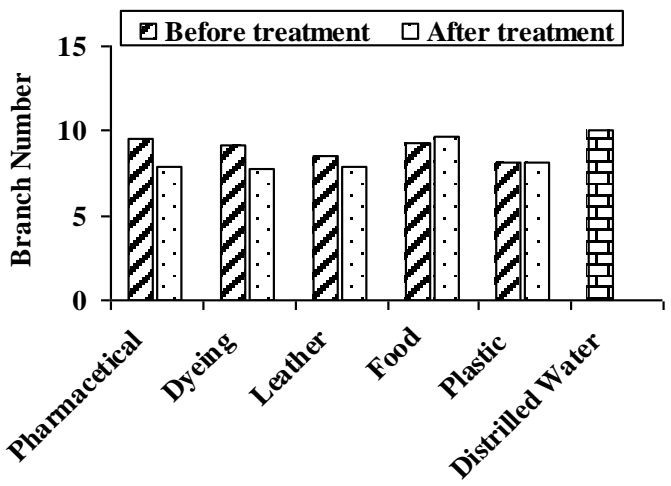

treated plant compared to the plant yield treated with distilled water.

\section{Trace elements in red amaranth}

The mean concentration of trace elements was detected in edible parts of red amaranth treated with industrial wastewater. The mean concentration range of $\mathrm{Pb}, \mathrm{Cd}$, $\mathrm{Ni}, \mathrm{Cr}, \mathrm{As}, \mathrm{Zn}$ and $\mathrm{Cu}$ in red amaranth was 0.1 to 0.9 , 0.06 to $0.2,0.1$ to $1.2,0.1$ to $50.7,0.1$ to $0.5,0.3$ to 0.8 , 0.2 to $2.6 \mu \mathrm{g} \mathrm{g}^{-1}$, respectively (Table 3 ). In general, leafy vegetables (red amaranth, radish, Indian spinach (green), stem amaranth leaf, jute leaf and coriander) accumulated much higher concentrations of $\mathrm{Pb}, \mathrm{Ni}$ and As compared to non-leaf vegetables (Itanna, 2002). Among all the analysed trace elements, $\mathrm{Cr}$ concentration showed the higher value (52.7 and 26.1 $\mu \mathrm{g}^{-1}$ ) as influenced by irrigation with discharged wastewater of leather and dyeing industries. Concentration of $\mathrm{Cd}$ showed the lower value $(0.06 \mu \mathrm{g} g$ $\left.{ }^{1}\right)$ and higher content of $\mathrm{Cd}$ was $0.2 \mu \mathrm{g} \mathrm{g}$. The concentration of $\mathrm{Ni}$ indicated that growth of red amaranth also influenced by it. Hossain et al. (2015) detected the approximate concentration of $\mathrm{Ni}(0.07$ to $\left.1.0 \mu \mathrm{g} \mathrm{g}^{-1}\right)$ in jute leaf, $\left(0.7 \mu \mathrm{g} \mathrm{g}^{-1}\right)$ in red amaranth and $\mathrm{Pb}$ concentration in stem amaranth was $0.1 \mu \mathrm{g} \mathrm{g}^{-1}$ which was lower than the values reports from an experiment.

B

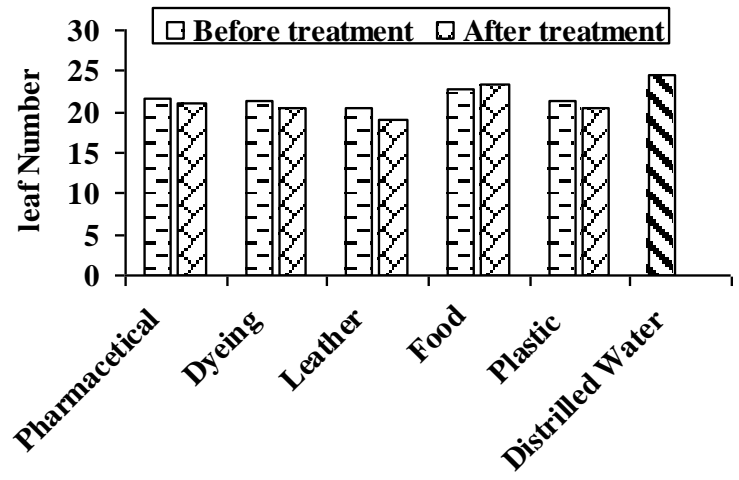


C

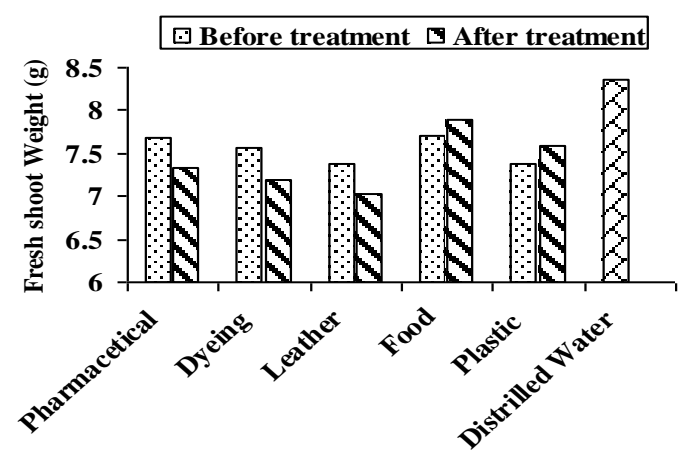

D

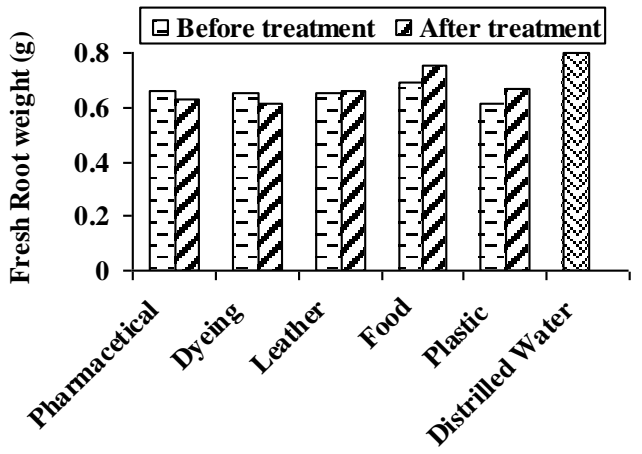

Fig. 2. Average branch (A) and leaf number (B), fresh shoot (C) and root weight (D) of red amaranth before and after wastewater treatment

Table 2. Yield of red amaranth compared to distilled water treatment

$\begin{array}{ccccccc}\text { Treatments } & \mathrm{T}_{2} & \mathrm{~T}_{3} & \mathrm{~T}_{4} & \mathrm{~T}_{5} & \mathrm{~T}_{6} & \mathrm{~T}_{1} \\ \text { Mean value }(\mathbf{g}) & 7.96 & 7.81 & 7.69 & 8.64 & 8.25 & \\ \text { Growth reduction in }(\mathbf{g}) & 0.99 & 1.14 & 1.26 & 0.31 & 0.7 & 8.95 \\ \text { Growth reduction in }(\boldsymbol{\%}) & 11.06 & 12.73 & 14.07 & 3.46 & 7.82 & \end{array}$

Table 3. Trace element contents of red amaranth as influenced by different treatments

\begin{tabular}{cccccccc}
\hline Treatments & $\mathbf{P b}$ & $\mathbf{C d}$ & $\mathbf{N i}$ & $\mathbf{C r}$ & $\mathbf{A s}$ & $\mathbf{Z n}$ & $\mathbf{C u}$ \\
\hline $\mathrm{T}_{2}$ & 0.97 & 0.10 & 0.26 & 0.16 & 0.33 & 0.40 & 0.67 \\
$\mathrm{~T}_{3}$ & 0.55 & 0.20 & 1.23 & 26.16 & 0.48 & 0.41 & 2.62 \\
$\mathrm{~T}_{4}$ & 0.42 & 0.14 & 0.58 & 50.72 & 0.52 & 0.85 & 0.57 \\
$\mathrm{~T}_{5}$ & 0.16 & 0.06 & 0.11 & 0.14 & 0.13 & 0.31 & 0.21 \\
$\mathrm{~T}_{6}$ & 0.20 & 0.06 & 0.11 & 0.33 & 0.16 & 0.54 & 0.26 \\
\hline
\end{tabular}

Conclusions

The growth of red amaranth after wastewater treatment of pharmaceuticals, dyeing, and leather industries was reduced. Reduction of plant yield treated with wastewater of pharmaceuticals, dyeing, leather, food, and plastic industries was $0.9,1.1,1.2,0.3$ and $0.7 \mathrm{~g}$, respectively compared to distilled water treated plant yield of $8.9 \mathrm{~g}$. This indicates that toxic metals or other substance present in the wastewater samples that inhibited the growth of red amaranth. It may be concluded that irrigation by untreated wastewater may hamper the normal growth of leafy vegetables. Regular monitoring of wastewater irrigated crops is needed to minimize the accumulation of various toxic metals in plant parts and to prevent the possible health hazards due to the consumption of toxic metals.

\section{Acknowledgements}

The research was supported with the help of BINA, Laboratory of Agricultural chemistry, BARI and Ministry of Science and Technology by providing funds.

\section{References}

Akan, J. C.; Rahman, A. F. I.; Ogugbuaja, V. O. and Ayodele, J. T. 2009. Heavy metals and anion levels in some samples of vegetables grown within the vicinity of Challawaindust. Area, Kano state, Nigeria. American Jounal of Applied Science 6(3): 534-542.

Funtua, M. A.; Agbaji, F. B. and Ajibola, V. O. 2008. Assessment of the heavy metal contents of spinach and lettuce grown along the bank of river Getsi, Kano J. Chem. Soc. Niger., 5(1): 11-14.

Goel, P. K. 2006. Water Pollution: Causes, Effects and Control, $2^{\text {nd }}$ Edition. New Age International Publisher, New Delhi.

Guo, J.; Dai, X.; Xu, W. and Ma, M. 2008. Over expressing GSHI and AsPCSI simultaneously increases the tolerance and accumulation of cadmium and arsenic in Arabidopsis thaliana. Chemosphere, 72: 1020-1026

Hossain, M. S.; Fahad, A.; Abu, T.; Mohammad, A.; Ahedul, A. and Mohammad, A. A. 2015. Public Health Risk Assessment of Heavy Metal Uptake by Vegetables Grown at a Waste-water-Irrigated Site in Dhaka, Bangladesh. Journal of Health and Pollution, 5: 9.

Islam, T. M.; Islam, S. M. and Hoque, S. M. 2006. Properties of Some Selected Soil under Mymensingh District in Bangladesh. Engineering Section, Bangladesh Agricultural University, Mymensingh, Bangladesh.

Itanna, F. 2002. Metals in leafy vegetables grown in Addis Ababa and toxicological implications Ethiopian Journal of Health Development, 6(3): 295-302.

Joshi, U. N.; Rathore, S. S. and Arora, S. K. 1999. Effect of chromium on growth and development of cow pea. Indian J. of environ. Prot., 19(10): 157-162

Keraita, B.; Jimenez, B. and Drechsel, P. 2008. Extent and implications of Aggarawal, G.D. undated. Waste management and pollution control for Bangladesh sugar factories and distilleries.

Scott, C. A.; Faruqui, N. I. and Raschid-Sally, L. 2004. Wastewater Use in Irrigated Agriculture: Confronting the Livelihood and Environmental Realities. 